\title{
Halobacillus yeomjeoni sp. nov., isolated from a marine solar saltern in Korea
}

\author{
Jung-Hoon Yoon, So-Jung Kang, Choong-Hwan Lee, Hyun Woo Oh \\ and Tae-Kwang Oh
}

Correspondence

Jung-Hoon Yoon

jhyoon@kribb.re.kr
Korea Research Institute of Bioscience and Biotechnology (KRIBB), PO Box 115, Yusong, Taejon, Republic of Korea

\begin{abstract}
A Gram-positive or Gram-variable, motile, endospore-forming, halophilic bacterial strain, MSS $-402^{\top}$, was isolated from a marine solar saltern in Korea, and subjected to a polyphasic taxonomic study. Some cells of strain MSS $-402^{\top}$ were long filamentous rods. The isolate grew optimally at $37^{\circ} \mathrm{C}$ and in the presence of 3-5\% (w/v) NaCl. Strain MSS-402 ${ }^{\top}$ had cell-wall peptidoglycan based on L-Orn-D-Asp, MK-7 as the predominant menaquinone and anteiso- $\mathrm{C}_{15: 0 \text {, }}$ anteiso- $\mathrm{C}_{17: 0}$ and iso- $\mathrm{C}_{16: 0}$ as major fatty acids. The DNA G+C content was $42.9 \mathrm{~mol} \%$. Phylogenetic analyses based on 16S rRNA gene sequences showed that strain MSS $-402^{\top}$ falls within the evolutionary radiation of species of the genus Halobacillus. Levels of 16S rRNA gene sequence similarity between strain MSS $-402^{\top}$ and the type strains of recognized Halobacillus species ranged from $98.0 \%$ (with Halobacillus halophilus) to $99.2 \%$ (with Halobacillus litoralis and Halobacillus trueperi). Levels of DNA-DNA binding indicated that strain MSS $-402^{\top}$ represents a genomic species that is distinct from recognized Halobacillus species. Strain MSS $-402^{\top}$ was differentiated from Halobacillus species by means of several phenotypic characteristics. On the basis of its phenotypic properties and phylogenetic and genetic distinctiveness, strain MSS $-402^{\top}$ (=KCTC $3957^{\top}=\mathrm{DSM} 17110^{\top}$ ) should be classified as the type strain of a novel Halobacillus species, for which the name Halobacillus yeomjeoni sp. nov. is proposed.
\end{abstract}

The genus Halobacillus was first described by Spring et al. (1996); at present, it comprises six species with validly published names, Halobacillus halophilus, Halobacillus litoralis and Halobacillus trueperi (Spring et al., 1996), Halobacillus salinus (Yoon et al., 2003), Halobacillus karajensis (Amoozegar et al., 2003) and Halobacillus locisalis (Yoon et al., 2004).

The genus Halobacillus is differentiated from the genus Bacillus and other related genera as having a cell-wall peptidoglycan type based on L-Orn-D-Asp (Spring et al., 1996; Shida et al., 1997; Yoon et al., 2001, 2002; Lim et al., 2005). Recently, in the course of screening for novel microorganisms present in marine solar salterns of the west coast of the Korean peninsula, a Halobacillus-like bacterial strain, MSS- $402^{\mathrm{T}}$, was isolated and characterized taxonomically. In this study, we focused on strain MSS $-402^{\mathrm{T}}$ because it was found to have an interesting morphological property, i.e. some cells are crooked, long, filamentous rods. The aim of the present work was to investigate the exact taxonomic

Published online ahead of print on 22 July 2005 as DOI 10.1099/ ijs.0.63801-0.

The GenBank/EMBL/DDBJ accession number for the 16S rRNA gene sequence of strain MSS- $402^{\top}$ is AY881246. status of strain MSS $-402^{\mathrm{T}}$ by using polyphasic taxonomic characterization.

Water collected from a marine solar saltern at Seosan, Korea, provided the source for isolation of the bacterial strains. A standard dilution plating technique was used to isolate strain MSS $-402^{\mathrm{T}}$ at $30^{\circ} \mathrm{C}$ on marine agar 2216 (MA; Difco) supplemented with $8 \%(\mathrm{w} / \mathrm{v}) \mathrm{NaCl}$. H. halophilus KCTC $3685^{\mathrm{T}}, H$. litoralis KCTC $3687^{\mathrm{T}}$ and H. trueperi KCTC $3686^{\mathrm{T}}$ were obtained from the Korean Collection for Type Cultures, Taejon, Korea. H. karajensis DSM $14948^{\mathrm{T}}$ was obtained from the Deutsche Sammlung von Mikroorganismen und Zellkulturen, Braunschweig, Germany. H. salinus HSL- $3^{\mathrm{T}}$ and H. locisalis MSS $-155^{\mathrm{T}}$ were obtained from the studies of Yoon et al. (2003, 2004). To investigate its morphological, physiological and biochemical characteristics, strain MSS $-402^{\mathrm{T}}$ was routinely cultivated on MA supplemented with $3 \%(\mathrm{w} / \mathrm{v}) \mathrm{NaCl}$ at $30^{\circ} \mathrm{C}$. The cell morphology was examined by light microscopy (E600; Nikon) and transmission electron microscopy. For the latter, the cells were negatively stained with $1 \%(\mathrm{w} / \mathrm{v})$ phosphotungstic acid and, after air-drying, the grids were examined by using a model CM-20 transmission electron microscope (Philips). The presence of flagella was examined by transmission electron microscopy using cells from 
exponentially growing cultures. The Gram-reaction was determined using the bioMérieux Gram Stain kit according to the manufacturer's instructions. Growth under anaerobic conditions was determined after incubation in an anaerobic chamber on MA supplemented with $3 \%(\mathrm{w} / \mathrm{v})$ $\mathrm{NaCl}$ and on MA supplemented with $3 \%(w / v) ~ N a C l$ and nitrate, both of which had been prepared anaerobically using nitrogen. The optimal $\mathrm{pH}$ for growth was determined in trypticase soy broth (Difco), supplemented with $3 \%$ $(\mathrm{w} / \mathrm{v}) \mathrm{NaCl}$ and $4.53 \mathrm{~g} \mathrm{MgCl}_{2} \cdot 6 \mathrm{H}_{2} \mathrm{O}$ (l distilled water) ${ }^{-1}$, that was adjusted to various $\mathrm{pH}$ values $(\mathrm{pH} 4.0$ initially, rising to $\mathrm{pH} 10.5$ at intervals of $0.5 \mathrm{pH}$ units). The $\mathrm{pH}$ was adjusted prior to sterilization to various levels by the addition of $\mathrm{HCl}$ or $\mathrm{Na}_{2} \mathrm{CO}_{3}$. Growth in the absence of $\mathrm{NaCl}$ was investigated in trypticase soy broth without $\mathrm{NaCl}$, supplemented with $4.53 \mathrm{~g} \mathrm{MgCl}_{2} \cdot 6 \mathrm{H}_{2} \mathrm{O}$ (1 distilled water) ${ }^{-1}$. The requirement for ions for growth was investigated in trypticase soy broth supplemented with $3 \%(\mathrm{w} / \mathrm{v}) \mathrm{NaCl}$ using $\mathrm{MgCl}_{2} \cdot 6 \mathrm{H}_{2} \mathrm{O}, \mathrm{MgSO}_{4} \cdot 7 \mathrm{H}_{2} \mathrm{O}, \mathrm{KCl}$ or $\mathrm{CaCl}_{2}$ at the concentrations indicated by Bruns et al. (2001). Growth at various $\mathrm{NaCl}$ concentrations was investigated in marine broth 2216 (Difco) (more than $2 \%, \mathrm{w} / \mathrm{v}, \mathrm{NaCl}$ at intervals of $1 \%$ ) and in trypticase soy broth supplemented with $4.53 \mathrm{~g}$ $\mathrm{MgCl}_{2} .6 \mathrm{H}_{2} \mathrm{O}$ (l distilled water) ${ }^{-1}$ (less than $2 \%$, w/v, NaCl at intervals of $0.5 \%$ ). Growth at various temperatures $\left(4-50{ }^{\circ} \mathrm{C}\right)$ was measured on MA supplemented with $3 \%(\mathrm{w} /$ v) $\mathrm{NaCl}$. Oxidase and catalase activities and hydrolysis of casein and starch were determined as described by Cowan \& Steel (1965). Hydrolysis of Tweens 20, 40, 60 and 80 was determined as described by Cowan \& Steel (1965), with the modification that artificial sea water was used instead of distilled water. Hydrolysis of aesculin, gelatin and urea and nitrate reduction were determined as described by Lanyi (1987), with the modification that artificial sea water was used for preparation of media. The artificial sea water contained the following (l distilled water) ${ }^{-1}: 23.6 \mathrm{~g} \mathrm{NaCl}$, $0.64 \mathrm{~g} \mathrm{KCl}, 4.53 \mathrm{~g} \mathrm{MgCl}_{2} .6 \mathrm{H}_{2} \mathrm{O}, 5.94 \mathrm{~g} \mathrm{MgSO}_{4} .7 \mathrm{H}_{2} \mathrm{O}$ and $1.3 \mathrm{~g} \mathrm{CaCl}_{2} \cdot 2 \mathrm{H}_{2} \mathrm{O}$ (Bruns et al., 2001). $\mathrm{H}_{2} \mathrm{~S}$ production was tested as described by Bruns et al. (2001). Hydrolysis of hypoxanthine, tyrosine and xanthine was performed on MA supplemented with $3 \%(\mathrm{w} / \mathrm{v}) \mathrm{NaCl}$, using the substrate concentrations indicated by Cowan \& Steel (1965). Acid production from carbohydrates was determined as described by Leifson (1963). Enzyme activities and other physiological properties were determined using the API ZYM and API 20E systems (bioMérieux); the cell suspension used to inoculate the systems was prepared by using artificial sea water (Bruns et al., 2001).

Cell mass for analyses of the cell wall and menaquinones and for DNA extraction was produced in marine broth 2216 supplemented with $3 \%(\mathrm{w} / \mathrm{v}) \mathrm{NaCl}$ at $37^{\circ} \mathrm{C}$. Preparation of cell-wall peptidoglycan was carried out using the method described by Schleifer \& Kandler (1972), and the peptidoglycan structure was determined using an automated amino acid analyser (model L-8500A; Hitachi). Menaquinones were analysed as described by Komagata \& Suzuki (1987), using reverse-phase HPLC. Chromosomal
DNA was isolated and purified according to the method described previously (Yoon et al., 1996), with the exception that RNase T1 was used in combination with RNase A. For fatty acid methyl ester analysis, cell mass of strain MSS- $402^{\mathrm{T}}$ was harvested from agar plates after cultivation for 2 days at $37^{\circ} \mathrm{C}$ on MA supplemented with $3 \%(\mathrm{w} / \mathrm{v}) \mathrm{NaCl}$. The fatty acid methyl esters were extracted and prepared according to the standard protocol of the MIDI/Hewlett Packard Microbial Identification System (Sasser, 1990). The DNA $\mathrm{G}+\mathrm{C}$ content was determined by the method of Tamaoka \& Komagata (1984), with the modification that the DNA was hydrolysed and the resultant nucleotides were analysed by reverse-phase HPLC. The 16S rRNA gene was amplified by using a PCR with two universal primers, as described previously (Yoon et al., 1998). Sequencing of the $16 \mathrm{~S}$ rRNA gene and phylogenetic analysis were performed as described by Yoon et al. (2003). DNA-DNA hybridization was performed fluorometrically by the method of Ezaki et al. (1989), using photobiotin-labelled DNA probes and microdilution wells. Hybridization was performed with five replications for each sample. The highest and lowest values obtained for each sample were excluded, and the means of the remaining three values were quoted as the DNA-DNA binding values.

The morphological, cultural, physiological and biochemical characteristics of strain MSS- $402^{\mathrm{T}}$ are shown in Table 1 or are given in the species description below. Cells of strain MSS $-402^{\mathrm{T}}$ were Gram-variable rods or long filamentous rods, measuring $0 \cdot 4-0 \cdot 6 \times 2 \cdot 0-100 \mu \mathrm{m}$ after incubation on MA supplemented with $3 \%(\mathrm{w} / \mathrm{v}) \mathrm{NaCl}$ at $37^{\circ} \mathrm{C}$; a few cells greater than $100 \mu \mathrm{m}$ in length were also observed (Fig. 1). This cellular morphological property was not found in other Halobacillus species (Spring et al., 1996; Amoozegar et al., 2003; Yoon et al., 2003, 2004). Strain MSS- $402^{\mathrm{T}}$ required $\mathrm{Na}^{+}$and $\mathrm{Mg}^{2+}$ ions for growth, but did not require $\mathrm{K}^{+}$or $\mathrm{Ca}^{2+}$. The $16 \mathrm{~S}$ rRNA gene sequence of strain MSS- $402^{\mathrm{T}}$ determined in this study comprised $1522 \mathrm{nt}$, representing approximately $96 \%$ of the Escherichia coli $16 \mathrm{~S}$ rRNA gene sequence. Comparative 16S rRNA gene sequence analyses showed that strain MSS- $402^{\mathrm{T}}$ is phylogenetically most closely affiliated to the genus Halobacillus (Fig. 2). In the phylogenetic tree based on the neighbour-joining algorithm, strain MSS $-402^{\mathrm{T}}$ fell within the radiation of the cluster comprising Halobacillus species (Fig. 2). The same tree topology was found in trees generated with the maximumlikelihood and maximum-parsimony algorithms (data not shown). The $16 \mathrm{~S}$ rRNA gene sequence of strain MSS $-402^{\mathrm{T}}$ had similarity levels of $98 \cdot 0-99 \cdot 2 \%$ with respect to sequences of the type strains of recognized Halobacillus species (Fig. 2). Sequence similarities with respect to all other species included in the phylogenetic analysis were lower than $94 \cdot 8 \%$ (Fig. 2).

The chemotaxonomic properties of strain MSS- $402^{\mathrm{T}}$ support the result of monothetic phylogenetic classification, namely that the isolate might be a member of the genus Halobacillus. Cell-wall analysis showed that strain MSS $-402^{\mathrm{T}}$ 
Table 1. Differential phenotypic properties of Halobacillus species

Species: 1, H. yeomjeoni sp. nov.; 2, H. halophilus (data from Claus et al., 1983; Spring et al., 1996); 3, H. trueperi (Spring et al., 1996); 4, H. litoralis (Spring et al., 1996); 5, H. salinus (Yoon et al., 2003); 6, H. karajensis (Amoozegar et al., 2003): 7, H. locisalis (Yoon et al., 2004). All species are positive for catalase and oxidase. All species are negative for nitrate reduction (not determined for H. karajensis), urease, anaerobic growth and hydrolysis of tyrosine (not determined for $H$. karajensis). Symbols: +, positive; -, negative; w, weakly positive; $\mathrm{v}$, variable; ND, not determined.

\begin{tabular}{|c|c|c|c|c|c|c|c|}
\hline Characteristic & 1 & 2 & 3 & 4 & 5 & 6 & 7 \\
\hline Cell morphology & $\begin{array}{l}\text { Rods or long } \\
\text { filamentous rods }\end{array}$ & Cocci or oval & Rods & Rods & Rods & Rods & Rods \\
\hline Flagellation & Single & Single or peritrichous & Peritrichous & Peritrichous & Peritrichous & Absent & Single \\
\hline Gram staining & $+(\mathrm{v})$ & + & + & + & $+(\mathrm{v})$ & + & $+(\mathrm{v})$ \\
\hline Spore shape & Ellipsoidal & Spherical & $\begin{array}{l}\text { Ellipsoidal or } \\
\text { spherical }\end{array}$ & $\begin{array}{l}\text { Ellipsoidal or } \\
\text { spherical }\end{array}$ & Ellipsoidal & $\begin{array}{l}\text { Ellipsoidal or } \\
\text { spherical }\end{array}$ & Ellipsoidal \\
\hline Spore position & $\begin{array}{l}\text { Central or } \\
\text { subterminal }\end{array}$ & Central or lateral & $\begin{array}{l}\text { Central or } \\
\text { subterminal }\end{array}$ & $\begin{array}{l}\text { Central or } \\
\text { subterminal }\end{array}$ & $\begin{array}{l}\text { Central or } \\
\text { subterminal }\end{array}$ & $\begin{array}{l}\text { Central or } \\
\text { subterminal }\end{array}$ & $\begin{array}{l}\text { Central or } \\
\text { subterminal }\end{array}$ \\
\hline Colony colour & Light yellow & Orange & Orange & Orange & Pale orange-yellow & Cream or white & Light orange-yellow \\
\hline $\begin{array}{l}\text { Maximum temperature } \\
\text { for growth }\left({ }^{\circ} \mathrm{C}\right)\end{array}$ & 48 & 37 & 44 & 43 & 45 & 49 & 42 \\
\hline \multicolumn{8}{|l|}{ Growth at: } \\
\hline $\mathrm{pH} 5 \cdot 0$ & - & - & - & - & + & - & + \\
\hline $\mathrm{pH} 5 \cdot 5$ & - & - & - & - & + & - & + \\
\hline \multicolumn{8}{|l|}{ Growth with: } \\
\hline $0 \cdot 5 \% \mathrm{NaCl}$ & $+^{*}$ & - & + & + & + & - & - \\
\hline $25 \% \mathrm{NaCl}$ & - & - & + & + & - & - & - \\
\hline \multicolumn{8}{|l|}{ Hydrolysis of: } \\
\hline Aesculin & - & - & - & - & + & + & + \\
\hline Casein & + & + & - & - & + & + & - \\
\hline Gelatin & + & + & + & + & + & + & - \\
\hline Starch & - & + & - & - & - & + & + \\
\hline Tween 80 & + & - & - & - & + & - & + \\
\hline \multicolumn{8}{|l|}{ Acid production from: } \\
\hline D-Fructose & - & - & + & + & + & + & + \\
\hline D-Galactose & - & - & + & - & W & - & - \\
\hline Maltose & + & - & + & + & + & + & - \\
\hline Sucrose & + & - & + & + & + & - & + \\
\hline D-Xylose & - & - & - & + & - & - & - \\
\hline D-Glucose & + & - & + & + & + & + & + \\
\hline D-Mannitol & + & - & - & + & + & + & - \\
\hline D-Trehalose & + & - & + & + & + & $\mathrm{ND}$ & + \\
\hline $\begin{array}{l}\text { DNA G+C content } \\
(\mathrm{mol} \%)\end{array}$ & $42 \cdot 9$ & $40 \cdot 1-40 \cdot 9$ & 43 & 42 & 45 & $41 \cdot 3$ & $44 \cdot 0$ \\
\hline
\end{tabular}



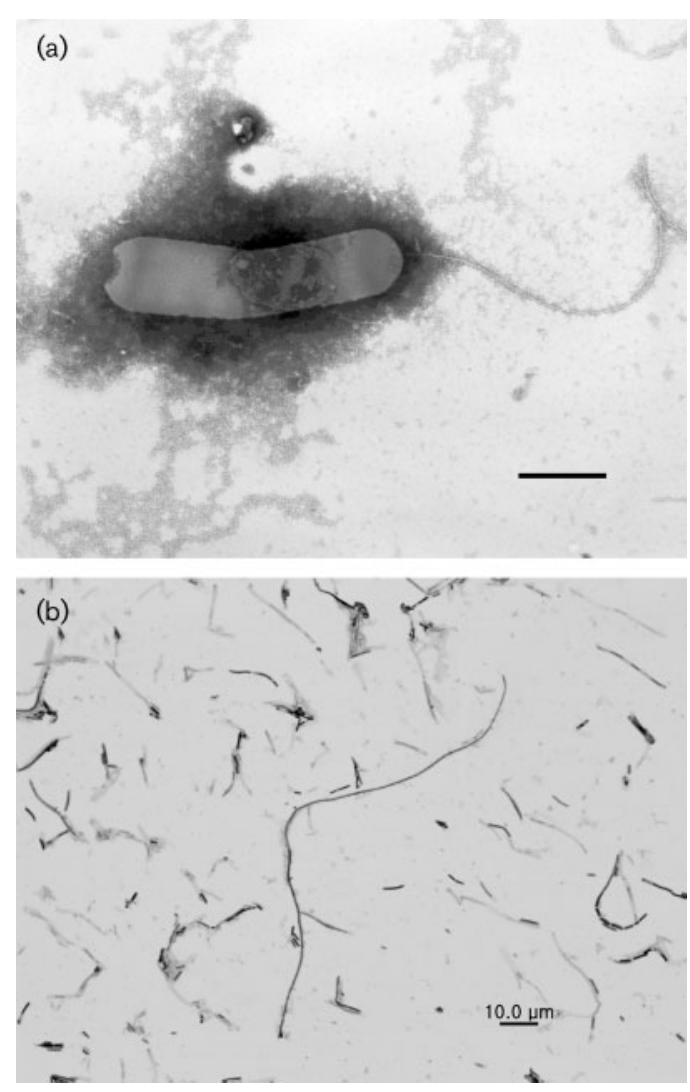

Fig. 1. Micrographs of strain MSS $-402^{\top}$ after cultivation for 3 days at $37^{\circ} \mathrm{C}$ on MA supplemented with $3 \%(\mathrm{w} / \mathrm{v}) \mathrm{NaCl}$. (a) Transmission electron micrograph. Bar, $1 \mu \mathrm{m}$. (b) Light micrograph. Bar, $10 \mu \mathrm{m}$.

had the peptidoglycan type A4 $\beta$, based on L-Orn-D-Asp, as described by Schleifer \& Kandler (1972). This cell-wall peptidoglycan type is a key marker that differentiates strain MSS $-402^{\mathrm{T}}$ and the genus Halobacillus from other aerobic or facultatively anaerobic, endospore-forming, rod-shaped genera (Spring et al., 1996; Shida et al., 1997; Wainø et al., 1999; Yoon et al., 2001). The predominant isoprenoid quinone found in strain MSS- $402^{\mathrm{T}}$ was unsaturated menaquinone with seven isoprene units (MK-7). The fatty acids detected in strain MSS $-402^{\mathrm{T}}$ were anteiso- $\mathrm{C}_{15: 0}$ $(40 \cdot 4 \%)$, anteiso- $\mathrm{C}_{17: 0}(23.0 \%)$, iso- $\mathrm{C}_{16: 0}(19 \cdot 3 \%)$, iso$\mathrm{C}_{15: 0}(8 \cdot 8 \%)$, iso- $\mathrm{C}_{17: 0}(3 \cdot 5 \%)$, iso- $\mathrm{C}_{14: 0}(3.4 \%)$ and $\mathrm{C}_{16: 0}(1 \cdot 6 \%)$. This fatty acid profile was similar to those of the type strains of Halobacillus species, although there were differences in the proportions of some fatty acids (Yoon et al., 2003, 2004). The DNA G + C content of strain MSS- $402^{\mathrm{T}}$ was $42 \cdot 9 \mathrm{~mol} \%$.

There were some differences between strain MSS- $402^{\mathrm{T}}$ and recognized Halobacillus species in terms of phenotypic characteristics (Table 1). DNA-DNA binding data were sufficient to categorize strain MSS- $402^{\mathrm{T}}$ as representing a species that is distinct from recognized Halobacillus species (Wayne et al., 1987). The mean DNA-DNA relatedness levels between strain MSS- $402^{\mathrm{T}}$ and the type strains of six recognized Halobacillus species were in the range 13-26\%. Therefore, on the basis of the data presented, strain MSS$402^{\mathrm{T}}$ should be placed in the genus Halobacillus as a member of a novel species, for which the name Halobacillus yeomjeoni sp. nov. is proposed.

\section{Description of Halobacillus yeomjeoni sp. nov.}

Halobacillus yeomjeoni (yeom.jeo'ni. N.L. gen. n. yeomjeoni of yeomjeon, the Korean name for a marine solar saltern).

Cells are rods or long filamentous rods, measuring $0 \cdot 4-0 \cdot 6 \times 2 \cdot 0-100 \mu \mathrm{m}$, on MA supplemented with $3 \%$ (w/v) $\mathrm{NaCl}$ at $37^{\circ} \mathrm{C}$; a few cells in old cultures are greater than $100 \mu \mathrm{m}$ in length (Fig. 1). Gram-positive, but Gramvariable in old cultures. Central or subterminal ellipsoidal endospores are observed in swollen sporangia. Colonies are circular, slightly raised, glistening, light yellow in colour and $1-2 \mathrm{~mm}$ in size after 2 days incubation at $30-37^{\circ} \mathrm{C}$ on MA supplemented with $3 \%(\mathrm{w} / \mathrm{v}) \mathrm{NaCl} \mathrm{Na}^{+}$and $\mathrm{Mg}^{2+}$ ions are required for growth. The optimal growth temperature is $37^{\circ} \mathrm{C}$; growth occurs at 15 and $48^{\circ} \mathrm{C}$, but not at 10 or $49^{\circ} \mathrm{C}$. The optimal $\mathrm{pH}$ for growth is $7 \cdot 0-8 \cdot 0$; growth occurs at $\mathrm{pH} 6 \cdot 0$, but not at $\mathrm{pH} 5 \cdot 5$. Optimal growth occurs in the presence of 3-5\% (w/v) NaCl; growth occurs in the presence of $0.5 \%(\mathrm{w} / \mathrm{v})$ and $21 \%(\mathrm{w} / \mathrm{v}) \mathrm{NaCl}$, but not without $\mathrm{NaCl}$

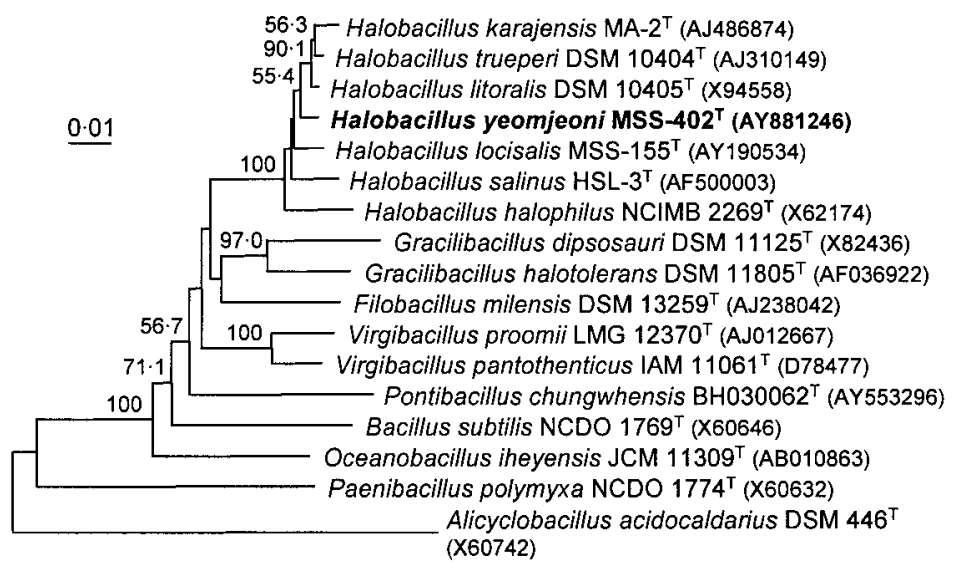

Fig. 2. Neighbour-joining tree, based on 16S rRNA gene sequence data, showing the phylogenetic positions of strain MSS$402^{\top}$, Halobacillus species and some other related taxa. Bootstrap values (1000 replications) are shown as percentages at each node only if they are $50 \%$ or greater. Bar, 0.01 substitutions per nucleotide position. 
or in the presence of $>22 \%(\mathrm{w} / \mathrm{v}) \mathrm{NaCl}$. Tweens 20, 40 and 60 are hydrolysed. Hypoxanthine and xanthine are not hydrolysed. The Voges-Proskauer test is negative. Indole and $\mathrm{H}_{2} \mathrm{~S}$ are not produced. Arginine dihydrolase, lysine decarboxylase and ornithine decarboxylase are absent. In assays with the API ZYM system, alkaline phosphatase, esterase $(\mathrm{C} 4)$, esterase lipase $(\mathrm{C} 8)$, naphthol-AS$\mathrm{BI}$-phosphohydrolase and $\beta$-galactosidase are present, but lipase (C14), leucine arylamidase, valine arylamidase, cystine arylamidase, trypsin, $\alpha$-chymotrypsin, acid phosphatase, $\alpha$-galactosidase, $\beta$-glucuronidase, $\alpha$-glucosidase, $\beta$-glucosidase, $N$-acetyl- $\beta$-glucosaminidase, $\alpha$-mannosidase and $\alpha$-fucosidase are absent. Acid is produced from Dcellobiose, D-ribose and D-mannose. Acid is not produced from L-arabinose, lactose, D-melezitose, melibiose, Draffinose, L-rhamnose, myo-inositol or D-sorbitol. The cell wall contains peptidoglycan based on L-Orn-D-Asp. The predominant menaquinone is MK-7. The major fatty acids are anteiso- $\mathrm{C}_{15: 0}(40 \cdot 4 \%)$, anteiso- $\mathrm{C}_{17: 0}(23.0 \%)$ and iso- $\mathrm{C}_{16: 0}(19 \cdot 3 \%)$. The DNA G $+\mathrm{C}$ content is $42.9 \mathrm{~mol} \%$.

The type strain, MSS $-402^{\mathrm{T}}\left(=\mathrm{KCTC} 3957^{\mathrm{T}}=\mathrm{DSM} 17110^{\mathrm{T}}\right)$, was isolated from a marine solar saltern of the Yellow Sea in Korea.

\section{Acknowledgements}

This work was supported by the 21C Frontier program of Microbial Genomics and Applications (grant MG02-0401-001-1-0-0) from the Ministry of Science and Technology (MOST) of the Republic of Korea.

\section{References}

Amoozegar, M. A., Malekzadeh, F., Malik, K. A., Schumann, P. \& Spröer, C. (2003). Halobacillus karajensis sp. nov., a novel moderate halophile. Int J Syst Evol Microbiol 53, 1059-1063.

Bruns, A., Rohde, M. \& Berthe-Corti, L. (2001). Muricauda ruestringensis gen. nov., sp. nov., a facultatively anaerobic, appendaged bacterium from German North Sea intertidal sediment. Int J Syst Evol Microbiol 51, 1997-2006.

Claus, D., Fahmy, F., Rolf, H. J. \& Tosunoglu, N. (1983). Sporosarcina halophila sp. nov., an obligate, slightly halophilic bacterium from salt marsh soils. Syst Appl Microbiol 4, 496-506.

Cowan, S. T. \& Steel, K. J. (1965). Manual for the Identification of Medical Bacteria. London: Cambridge University Press.

Ezaki, T., Hashimoto, Y. \& Yabuuchi, E. (1989). Fluorometric deoxyribonucleic acid-deoxyribonucleic acid hybridization in microdilution wells as an alternative to membrane filter hybridization in which radioisotopes are used to determine genetic relatedness among bacterial strains. Int J Syst Bacteriol 39, 224-229.

Komagata, K. \& Suzuki, K. (1987). Lipids and cell-wall analysis in bacterial systematics. Methods Microbiol 19, 161-203.

Lanyi, B. (1987). Classical and rapid identification methods for medically important bacteria. Methods Microbiol 19, 1-67.
Leifson, E. (1963). Determination of carbohydrate metabolism of marine bacteria. J Bacteriol 85, 1183-1184.

Lim, J.-M., Jeon, C. O., Song, S. M. \& Kim, C.-J. (2005). Pontibacillus chungwhensis gen. nov., sp. nov., a moderately halophilic Grampositive bacterium from a solar saltern in Korea. Int J Syst Evol Microbiol 55, 165-170.

Sasser, M. (1990). Identification of Bacteria by Gas Chromatography of Cellular Fatty Acids. Newark, DE: MIDI.

Schleifer, K. H. \& Kandler, O. (1972). Peptidoglycan types of bacterial cell walls and their taxonomic implications. Bacteriol Rev 36, 407-477.

Shida, O., Takagi, H., Kadowaki, K., Nakamura, L. K. \& Komagata, K. (1997). Transfer of Bacillus alginolyticus, Bacillus chondroitinus, Bacillus curdlanolyticus, Bacillus glucanolyticus, Bacillus kobensis, and Bacillus thiaminolyticus to the genus Paenibacillus and emended description of the genus Paenibacillus. Int J Syst Bacteriol 47, 289-298.

Spring, S., Ludwig, W., Marquez, M. C., Ventosa, A. \& Schleifer, K.-H. (1996). Halobacillus gen. nov., with description of Halobacillus litoralis sp. nov. and Halobacillus trueperi sp. nov., and transfer of Sporosarcina halophila to Halobacillus halophilus comb. nov. Int J Syst Bacteriol 46, 492-496.

Tamaoka, J. \& Komagata, K. (1984). Determination of DNA base composition by reverse-phase high-performance liquid chromatography. FEMS Microbiol Lett 25, 125-128.

Wainø, M., Tindall, B. J., Schumann, P. \& Ingvorsen, K. (1999). Gracilibacillus gen. nov., with description of Gracilibacillus halotolerans gen. nov., sp. nov.; transfer of Bacillus dipsosauri to Gracilibacillus dipsosauri comb. nov., and Bacillus salexigens to the genus Salibacillus gen. nov., as Salibacillus salexigens comb. nov. Int J Syst Bacteriol 49, 821-831.

Wayne, L. G., Brenner, D. J., Colwell, R. R. \& 9 other authors (1987). International Committee on Systematic Bacteriology. Report of the ad hoc committee on reconciliation of approaches to bacterial systematics. Int J Syst Bacteriol 37, 463-464.

Yoon, J.-H., Kim, H., Kim, S.-B., Kim, H.-J., Kim, W. Y., Lee, S. T., Goodfellow, M. \& Park, Y.-H. (1996). Identification of Saccharomonospora strains by the use of genomic DNA fragments and rRNA gene probes. Int J Syst Bacteriol 46, 502-505.

Yoon, J.-H., Lee, S. T. \& Park, Y.-H. (1998). Inter- and intraspecific phylogenetic analysis of the genus Nocardioides and related taxa based on 16S rDNA sequences. Int J Syst Bacteriol 48, 187-194.

Yoon, J.-H., Weiss, N., Lee, K.-C., Lee, I.-S., Kang, K. H. \& Park, Y.-H. (2001). Jeotgalibacillus alimentarius gen. nov., sp. nov., a novel bacterium isolated from jeotgal with L-lysine in the cell wall, and reclassification of Bacillus marinus Rüger 1983 as Marinibacillus marinus gen. nov., comb. nov. Int J Syst Evol Microbiol 51, 2087-2093.

Yoon, J.-H., Kang, K. H. \& Park, Y.-H. (2002). Lentibacillus salicampi gen. nov., sp. nov., a moderately halophilic bacterium isolated from a salt field in Korea. Int J Syst Evol Microbiol 52, 2043-2048.

Yoon, J.-H., Kang, K. H. \& Park, Y.-H. (2003). Halobacillus salinus sp. nov., isolated from a salt lake on the coast of the East Sea in Korea. Int J Syst Evol Microbiol 53, 687-693.

Yoon, J.-H., Kang, K. H., Oh, T.-K. \& Park, Y.-H. (2004). Halobacillus locisalis sp. nov., a halophilic bacterium isolated from a marine solar saltern of the Yellow Sea in Korea. Extremophiles 8, 23-28. 